\title{
Эпидемиологическая ситуация по новой коронавирусной инфекции (COVID-19) в Ростовской области: анализ и прогноз
}

\author{
Е.В. Ковалев ${ }^{1,4}$, Т.И. Твердохлебова ${ }^{2,4}$, Г.В. Карпущенко ${ }^{3,4}$, Е.Г. Ерганова ${ }^{1}$, В.В. Агафонова ${ }^{2}$, \\ А.А. Рындич ${ }^{2}$, А.Г. Суладзе ${ }^{2}$, Д.С. Колпаков ${ }^{2}$, Н.Н. Долгова ${ }^{2}$, Н.В. Алексанина ${ }^{2}$, \\ А.В. Алешукина ${ }^{2}$, А.Р. Литовко ${ }^{3}$, Г.С. Алешукин ${ }^{2}$, В.В. Денисенко ${ }^{2}$ \\ ${ }^{1}$ Уравление Федеральной службы по надзору в сфере зашиты прав потребителей и благополучия \\ человека по Ростовской области, Ростов-на-Дону, Россия \\ ${ }^{2}$ Ростовский научно-исследовательский институт микробиологии и паразитологии \\ Роспотребнадзора, Ростов-на-Дону, Россия \\ ${ }^{3}$ Центр гигиены и эпидемиологии в Ростовской области, Ростов-на-Дону, Россия \\ ${ }^{4}$ Ростовский государственный медицинский университет, Ростов-на-Дону, Россия
}

\begin{abstract}
Цель: мониторинг, анализ и прогноз распространения новой коронавирусной инфекции (COVID-19) в Ростовской области. Материалы и методы: анализ данных по заболеваемости COVID-19 в Ростовской области, полученных на базе учреждений Роспотребнадзора: Управления Роспотребнадзора по Ростовской области, ФБУЗ «Центр гигиены и эпидемиологии в Ростовской области», ФБУН РостовНИИ микробиологии и паразитологии, а также мониторинг информации на Интернет-сайтах Правительства Ростовской области и регионального штаба по борьбе с распространением COVID-19. Применение аналитической платформы SEIR для построения математической модели прогноза распространения инфекции в Ростовской области. Результаты: в работе представлен анализ эпидемиологической ситуации по заболеваемости COVID-19 в Ростовской области, анализ эффективности реализации профилактических и противоэпидемических мероприятий с возможностью прогнозирования развития эпидемического процесса в регионе.

Ключевые слова: коронавирусная инфекция, COVID-19, эпидемиологическая ситуация, прогноз, противоэпидемические мероприятия.

Для цитирования: Ковалев Е.В., Твердохлебова Т.И., Карпущенко Г.В., Ерганова Е.Г., Агафонова В.В., Рындич А.А., Суладзе А.Г., Колпаков Д.С., Долгова Н.Н., Алексанина Н.В., Алешукина А.В., Литовко А.Р., Алешукин Г.С., Денисенко B.В. Эпидемиологическая ситуация по новой коронавирусной инфекции (COVID-19) в Ростовской области: анализ и прогноз. Медицинский вестник Юга России. 2020;11(3):69-78. DOI 10.21886/2219-8075-2020-11-3-69-78.
\end{abstract}

Контактное лицо: Виктория Владиславовна Агафонова, niimicrodouble@yandex.ru.

\section{Epidemiological situation of a new coronavirus infection (COVID-19) in the Rostov region: analysis and forecast}

\author{
E.V. Kovalev ${ }^{1,4}$, T.I. Tverdokhlebova ${ }^{2,4}$, G.V. Karpushenko ${ }^{3}$, E.G. Erganova ${ }^{1}$, \\ V.V. Agafonova ${ }^{2}$, A.A. Ryndich ${ }^{2}$, A.G. Suladze ${ }^{2}$, D.S. Kolpakov' ${ }^{2}$ N.N. Dolgova ${ }^{2}$, \\ N.V. Aleksanina ${ }^{2}$, A.V. Aleshukina ${ }^{2}$, A.R. Litovko ${ }^{3}$, G.S. Aleshukin ${ }^{2}$, V.V. Denisenko² \\ ${ }^{1}$ Department of the Federal service for supervision of consumer protection and human welfare in the \\ Rostov region, Rostov-on-Don, Russia \\ ${ }^{2}$ Rostov research Institute of Microbiology and Parasitology, Rostov-on-Don, Russia \\ ${ }^{3}$ Center of hygiene and epidemiology in the Rostov region, Rostov-on-Don, Russia \\ ${ }^{4}$ Rostov State Medical University, Rostov-on-Don, Russia
}

\begin{abstract}
Objective: monitoring, analysis and forecast of the spread of new coronavirus infection (COVID-19) in the Rostov region. Materials and methods: analysis of data on the incidence of COVID-19 in the Rostov region, obtained on the basis of agencies: Department of the Federal service for supervision of consumer protection and human welfare in the Rostov region, Center of hygiene and epidemiology in Rostov region, Rostov research Institute of Microbiology and Parasitology, as well as the monitoring of information on the Internet sites of the Government of the Rostov region and the regional headquarters for the fight against the spread of COVID-19. Application of the SEIR analytical platform to build a mathematical model for predicting the spread
\end{abstract}


of infection in the Rostov region. Results: the article presents an analysis of the epidemiological situation for the incidence of COVID-19 in the Rostov region, analyzes the effectiveness of preventive and anti-epidemic measures with the ability to predict the development of the epidemiological process in the region.

Keywords: coronavirus infection, COVID-19, epidemiological situation, prognosis, anti-epidemic measures

For citation: Kovalev E.V., Tverdokhlebova T.I., Karpushenko G.V., Erganova E.G., Agafonova V.V., Ryndich A.A., Suladze A.G., Kolpakov D.S., Dolgova N.N., Aleksanina N.V., Aleshukina A.V., Litovko A.R., Aleshukin G.S., Denisenko V.V. Epidemiological situation of a new coronavirus infection (COVID-19) in the Rostov region: analysis and forecast. Medical Herald of the South of Russia. 2020;11(3):69-78. DOI 10.21886/2219-8075-2020-3-69-78.

Corresponding author: Victoria V. Agafonova, niimicrodouble@yandex.ru.

\section{Введение}

$\mathrm{O}$ фициальная информация о вспышке пневмонии неизвестной этиологии в городе Ухань (Wuhan City), столице провинции Хубэй (Hubei Province of China), появилась впервые 31 декабря 2019 г. из центра Всемирной организации здравоохранения (ВО3) в Китае (WHO China Country Office). С конца января 2020 г. во многих странах мира стали регистрироваться случаи заболевания COVID-19, преимущественно связанные с поездками в КНР. 30 января ВОЗ признала вспышку, вызванную новым коронавирусом, чрезвычайной ситуацией в области общественного здравоохранения, имеющей международное значение. 11 февраля 2020 г. Международный комитет по таксономии вирусов присвоил официальное название возбудителю инфекции SARS-CoV-2 (Severe acute respiratory syndrome coronavirus 2, второй коронавирус тяжелого острого респираторного синдрома), а 11 марта 2020 г. ВОЗ объявила о начале пандемии и присвоила официальное название инфекции, вызванной новым коронавирусом COVID-19 (Corona Virus Disease 2019, коронавирусная болезнь 2019 г. $)^{123}$.

С начала января 2020 г. специалистами Роспотребнадзора и Минздрава России предпринимаются экстренные меры по сдерживанию распространения инфекции на территории Российской Федерации ${ }^{4}$.

В России первые случаи инфекции, вызванной коронавирусом 2019-nCoV (SARS-CoV-2), были зафиксированы 31 января 2020 г. К настоящему моменту география распространения заболевания COVID-19 очень широка и захватывает более 190 стран мира. По данным ВОЗ, в мире по состоянию на 10.07.2020 зарегистрировано 12259738 подтверждённых случаев (Информационный бюллетень 10.07.2020 г.). Лидерами по числу зарегистрированных случаев COVID-19 являются США, Бразилия, Индия, Россия. В Российской Федерации на 10.07.2020 г. выявлено 707301 случаев заболевания в 85 регионах, летальных случаев - 10843.

До 2002 г. коронавирусы рассматривались в качестве агентов, вызывающих нетяжелые заболевания верхних дыхательных путей с крайне редкими летальными исходами. Однако в 2002 и 2012 гг. были зарегистрированы эпидемические вспышки заболеваний, вызванных коронавирусами SARS-CoV и MERS-CoV. В настоящее время известно о циркуляции среди населения четырех коронавирусов (HCoV-229E, -OC43, -NL63 и -HKU1), которые круглогодично присутствуют в структуре ОРВИ и, как правило, вызывают поражение верхних дыхательных путей легкой и средней степени тяжести ${ }^{5}$. Новый коронавиpyc SARS-CoV-2, проявивший пандемичный потенциал, предположительно является рекомбинантным вирусом между коронавирусом летучих мышей и неизвестным по происхождению коронавирусом. Генетическая последовательность SARS-CoV-2 сходна с последовательностью SARS-CoV, по меньшей мере, на 79 \%. Эпидемия COVID-2019 привлекла к себе внимание специалистов здравоохранения и населения во всем мире, так как ранее коронавирусные инфекции у людей не выходили за пределы допустимого уровня биологического риска. Однако последствия произошедших мутаций этих вирусов указывают на то, что трансформации последних могут приводить к чрезвычайным ситуациям ${ }^{6}$.

Появление нового варианта вируса и эпидемический потенциал, проявленный возбудителем COVID-19, поставили перед специалистами санитарно-эпидемиологической службы и здравоохранения задачи, связанные с быстрой разработкой диагностики и профилактики новой инфекции, а также тактики оказания медицинской помощи больным. В настоящее время вопросы эпидемиологии, клинических особенностей, профилактики и лечения этого заболевания находятся на стадии изучения. В связи с этим, мониторинг и анализ эпидемиологиче-

\footnotetext{
${ }^{1}$ Wuhan Municipal Health Commission briefi ng on the pneumonia epidemic situation. 31 December 2019 (in Mandarin). http://wjw.wuhan.gov.cn/ front/web/showDetail/2019123108989

${ }^{2}$ Pneumonia of unknown cause - China. Disease outbreak news. 5 January 2020. WHO. https://www.who.int/csr/don/05-january-2020-pneumoniaof-unkown-cause-china/en/

${ }^{3}$ Statement on the second meeting of the International Health Regulations (2005) Emergency Committee regarding the outbreak of novel coronavirus (2019-nCoV). https://www.who.int/emergencies/diseases/novel-coronavirus-2019/technical-guidance/naming-the-coronavirus-disease-(covid-2019)and-the-virus-that-causes-it

4 Информация Роспотребнадзора: https://rospotrebnadzor.ru/deyatelnost/epidemiological-surveillance/?ELEMENT_ID=13554; https://www. rosminzdrav.ru/news/2020/01/30/13236-vremennye-metodicheskie-rekomendatsii-po-profi laktike-diagnostike-i-lecheniyunovoy-koronavirusnoyinfektsii-2019-ncov

${ }^{5}$ CDC. 2019 Novel Coronavirus: https://www.cdc.gov/coronavirus/2019-ncov/index.html

${ }^{6}$ Coronavirus disease (COVID-2019) situation reports: https://www.who.int/emergencies/diseases/novel-coronavirus-2019?gclid=CjwKCAjwm
} 
Е.В. Ковалев, Т.И. Твердохлебова, Г.В. Карпущенко, Е.Г. Ерганова, В.В. Агафонова, А.А. Рындич, А.Г. Суладзе, Д.С. Колпаков, Н.Н. Долгова, Н.В. Алексанина и др. ЭПИДЕМИОЛОГИЧЕСКАЯ СИТУАЦИЯ ПО НОВОЙ КОРОНАВИРУСНОЙ ИНФЕКЦИИ (COVID-19) В РОСТОВСКОЙ ОБЛАСТИ: АНАЛИЗ И ПРОГНОЗ

ской ситуации по COVID-19 в различных субъектах Российской Федерации представляется весьма актуальным и значимым для понимания развития эпидемического процесса и составления прогноза [1].

В данной работе проведен анализ эпидемиологической ситуации по заболеваемости COVID-19 в Ростовской области, проанализирована эффективность реализации профилактических и противоэпидемических мероприятий с возможностью прогнозирования развития эпидемического процесса в регионе.

В Ростовской области первый случай выявления COVID-19 был зарегистрирован 25 марта 2020 г. у женщины, прибывшей из-за границы незадолго до проявления симптомов заболевания. С этого дня регистрировался единичный прирост случаев заболевания до 6 апреля 2020 г. Затем начали выявляться десятки случаев заболевания, а с 16 мая 2020 года - более 100 случаев ежедневно.

По данным Управления Роспотребнадзора по Ростовской области, количество подтверждённых инфицированных новым коронавирусом в области на 10 июля 2020 г. достигло 10533. Показатель заболеваемости на 100 тысяч населения - 251,0. Коэффициент распространения инфекции $-0,99$. Лабораториями Ростовской области за весь период проведено свыше 291,5 тысячи тестов на коронавирусную инфекцию. Охват населения тестированием методом ПЦР на 100 тыс. населения - 96,1. Диагностика COVID-19 в Ростовской области осуществляется на базе лабораторий трех учреждений Роспотребнадзора (ФБУЗ «Центр гигиены и эпидемиологии в Ростовской области», ФКУЗ «Ростовский-на-Дону противочумный институт», ФБУН РостовНИИ микробиологии и паразитологии) и 9-ти лабораторий медицинских организаций.

Случаи COVID-19 регистрируются в 12 городах и 43 районах Ростовской области. Наибольшее число случаев заболевания зарегистрировано в г. Ростове-на-Дону (3674 человек - 34,9\% от общего количества случаев), в городах Шахты (575), Батайск (389), Донецк (236), Зверево (245), Новошахтинск (287) в Сальском (646), Белокалитвинском (442), Мясниковском (331), Аксайском (273) районах.

Следует отметить, что в определенные периоды (23.05.2020 и 02.06.2020) в Ростовской области за сутки было выявлено "рекордное» количество новых случаев заболевания (353 и 253 случаев соответственно). Это связано с возникновением вспышки заболевания в социальных учреждениях (психоневрологических интернатах) Ростовской области в городах Сальск и Зверево.

За весь период в области медицинским наблюдением было охвачено более 61 тысячи человек, выздоровело 7760 заболевших, умерло - 156 человек.

На момент проведения анализа возрастная структура вновь выявленных случаев заболевания распределилась следующим образом: 46 - 65 лет - 44,6 \%, 18 - 45 лет $34,8 \%, 66$ - 79 лет - $13 \%$, старше 80 лет - 3,3\%, 0 - 17 лет $4,3 \%$. Как и в целом по общему количеству заболевших COVID-19 в области, среди вновь выявленных случаев преобладает возрастная группа 46 - 65 лет и 18 - 4 5 лет (рис. 1).

Распределение результатов тестирования на COVID-19 по контингентам, проведенного специалистами ФБУН РостовНИИ микробиологии и паразитологии Роспотребнадзора показало, что число положительных результатов среди медицинских работников составило $2,9 \%$, контактных - 12,3\%, здоровых лиц - 3,8\%, вернувшихся на территорию Российской Федерации - 8,3 \%, граждан, поступивших в дома-интернаты - 1,9\%.

Анализ летальных исходов показал, что среди умерших с COVID-19 преобладали пожилые лица с серьезными хроническими нарушениями сердечно-сосудистой системы (гипертоническая болезнь, ишемическая болезнь сердца и др.), тяжелыми нарушениями эндокринной системы и обмена веществ (сахарный диабет, ожирение и др.), хроническими заболеваниями дыхательной системы. Это может быть связано с определенными механизмами развития данной вирусной патологии, такими как массированное образование и циркуляция иммунных комплексов, цитокинов («цитокиновый шторм») в ответ на повреждающий агент, что приводит к повреждению эндотелия сосудов, соответственно повышению их проницаемости, а также нарушению сократительной способности миокарда. Перечисленные процессы обуславливают повышенный риск развития неблагоприятных исходов течения COVID-19 у пациентов с сопутствующими патологиями. По мнению ряда авторов, характер

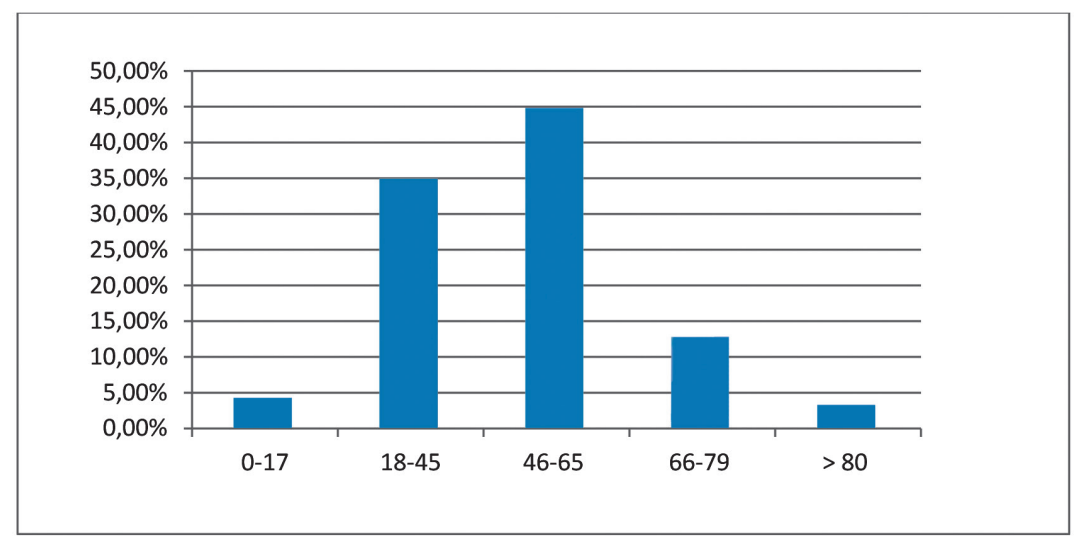

Рисунок 1. Возрастная структура заболевших COVID-19 в Ростовской области. Figure 1. Age structure of COVID-19 patients in the Rostov region. 
течения COVID-19 определяется генетическими особенностями экспрессии ангиотензин-превращающего фермента (АПФ2), который служит потенциальной мишенью для проникновения SARS-CoV-2 (АПФ2 впервые был описан Donoghue M. с соавторами в 2000 г., как молекула, экспрессируемая, преимущественно, эндотелием) $[2,3]$. АПФ2 локализуется в эндотелиальных клетках артерий и вен, гладкой мускулатуре артериальной стенки, эпителии респираторного тракта, эпителии тонкой кишки и иммунных клетках. [4].

Среди умерших в более молодом возрасте было отмечено позднее обращение больных за медицинской помощью. Спектр тяжелых хронических патологий и возрастной фактор свидетельствуют о том, что основными причинами смерти являются именно тяжелые соматические заболевания.

С середины июня 2020 г. наблюдается превалирование количества выздоровевших за сутки над количеством новых случаев инфицирования в день, а также стабилизация численного показателя смертей от новой коронавирусной инфекции (рис. 2).

Помесячный анализ развития эпидемического процесса позволил отметить следующие изменения: за первый месяц эпидемии COVID-19 в Ростовской области (на
30 апреля 2020 г.) показатель заболеваемости составлял 22,44 на 100 тыс. населения; за второй месяц (май 2020 г.) 90,78 (увеличился в 4,05 раза); за третий месяц эпидемии (июнь 2020 г.) - 227,7 (увеличился в 2,5 раза) (рис. 3).

При анализе активных случаев заражения, начиная с апреля, отмечен динамический рост показателей, продолжавшийся до 15.06.2020 г., а затем наблюдалось плавное снижение количества случаев до 92 - 97 до начала июля. Начиная с 09.04.2020 г., регистрируются случаи выздоровления с непрекращающейся положительной динамикой до 10.07.2020 г. При этом следует отметить, что до 06.05.2020 г. кумулятивное количество заболевших и количество активных случаев заражения были на одном уровне. Затем имело место снижение активных случаев на фоне роста общего количества заболевших, что следует рассматривать, как благоприятную динамику развития эпидемического процесса.

Стабилизации к концу первой декады июля эпидемиологической ситуации по COVID-19 в Ростовской области способствовала реализация комплекса профилактических и противоэпидемических мероприятий органами и организациями Роспотребнадзора совместно с Минздравом Ростовской области и муниципальными властями региона, проводимого в рамках Национального плана

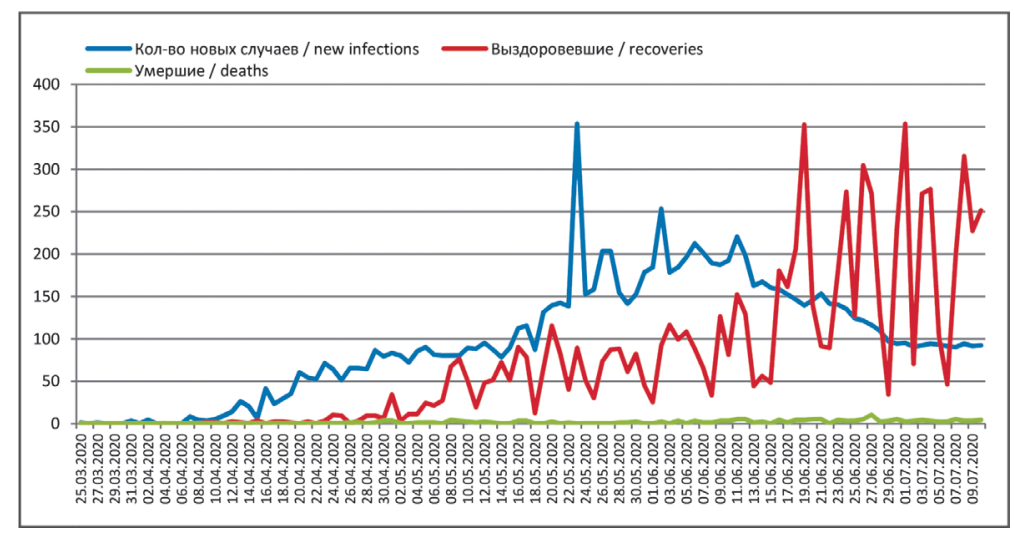

Рисунок 2. Динамика регистрации новых случаев заражения, смертей и выздоровлений от COVID-19 в Ростовской области.

Figure 2. Dynamics of registration of new infections, deaths and recoveries from COVID-19 in the Rostov region.

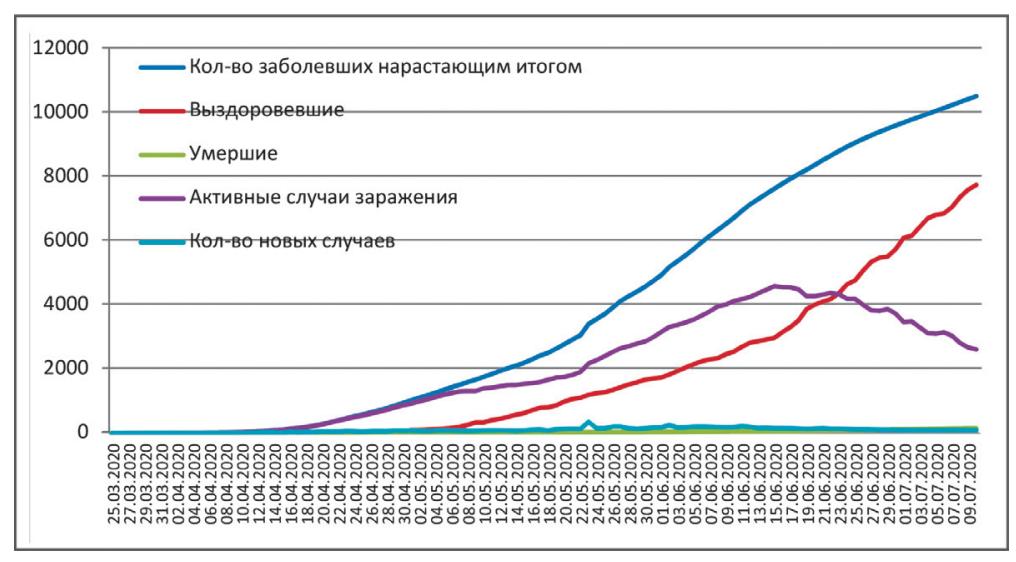

Рисунок 3. Динамическое наблюдение за активностью эпидемического процесса COVID-19 в Ростовской области. Figure 3. Dynamic monitoring of the activity of the COVID-19 epidemic process in the Rostov region. 


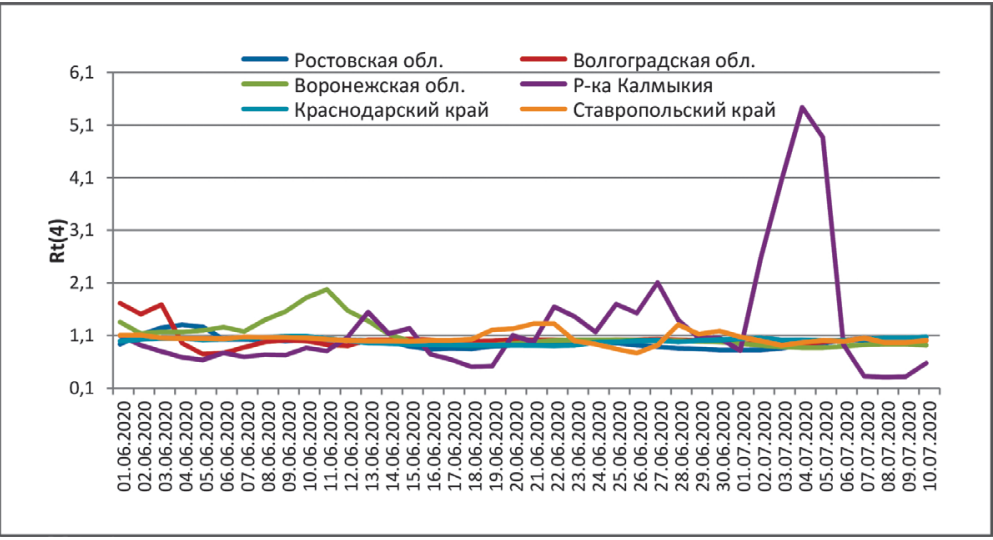

Рисунок 4. Динамика коэффициента распространения (Rt) COVID-19 в период с 01.06.2020 г. по 10.07.2020 г. на территории Ростовской области и смежных территориях.

Figure 4. Dynamics of the COVID-19 distribution coefficient (Rt) in the period from 01.06.2020 to 10.07.2020 on the territory of the Rostov region and adjacent territories.

по предупреждению завоза и распространения новой коронавирусной инфекции на территории Российской Федерации, утвержденного Председателем Правительства Российской Федерации и Постановлений Главного государственного санитарного врача Российской Федерации. Однако, следует отметить возможное осложнение эпидситуации к концу июля, обусловленное отменой некоторых ограничительных мероприятий.

Был проведен анализ эффективности мероприятий по сдерживанию распространения новой коронавирусной инфекции в Ростовской области, которые включали, в частности, меры по ограничению передвижения между субъектами Российской Федерации, граничащими с Ростовской областью. За период с 01.06.2020 г. по 10.07.2020 г. проведено сравнение показателей коэффициента распространения COVID-19, как основного индикатора эпидемического процесса, на следующих территориях: в Ростовской, Волгоградской, Воронежской областях, в Краснодарском и Ставропольском краях и в Республике Калмыкия.

Установлено, что коэффициент распространения инфекции (Rt) с начала и до середины июня был близок между Ростовской областью, Краснодарским и Ставропольским краями. Однако после 15.06.2020 г. в Ставропольском крае Rt резко возрос, а с 23.06.2020 г. наблюдалось его снижение. В Воронежской области Rt до середины июня был выше, чем на других территориях, а затем произошло его снижение и стабилизация. На 10.07.2020 г. отмечалась стабилизация показателя Rt на одинаковом уровне на всех рассматриваемых территориях, за исключением Республики Калмыкия, где прослеживается своя характерная особенность динамики данного критерия. В начале июля на территории Республики была зафиксирована крупная вспышка COVID-19 в Сарпинском психоневрологическом доме-интернате, которая сопровождалась резким подъемом Rt в период с 01.07.2020 г. по 06.07.2020 г., с пиком на 04.07.2020 г. $(\mathrm{Rt}=5,41)$. В дальнейшем наблюдалось снижение изучаемого показателя, без тенденции к стабилизации (рис. 4).

По показателям количества заражений COVID-19 на 100 тыс. населения территории, имеющие общие границы с
Ростовской областью, распределились следующим образом: Республика Калмыкия - 734, Воронежская область - 378, Волгоградская область - 284, Ставропольский край -208 , Краснодарский край - 114. Красным полем отмечены города и районы Ростовской области с наиболее высокими уровнями заболеваемости (рис. 5).

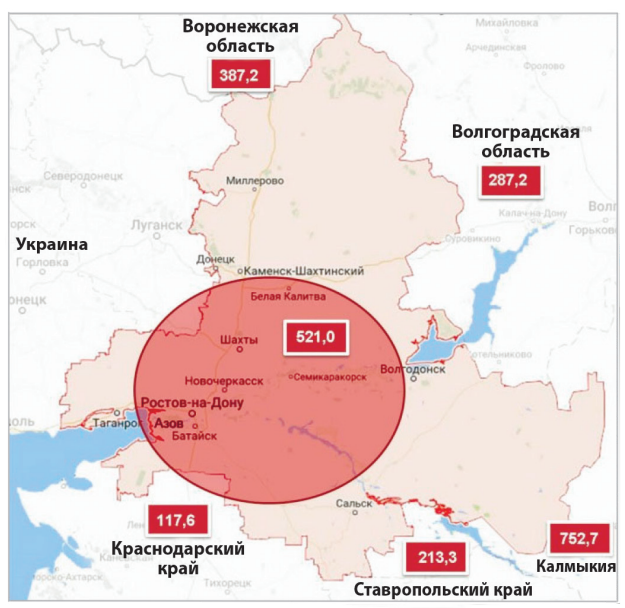

Рисунок 5. Показатели количества заражений COVID-19 на 100 тыс. населения в Ростовской области и на смежных территориях.

Figure 5. Indicators of the number of COVID-19 infections per 100 thousand population in the Rostov region and adjacent territories.

Исходя их полученных результатов, можно сделать вывод о том, что интенсивность развития эпидемического процесса на территории Ростовской области зависела в большей степени от удаленности районов по отношению к областному центру (г. Ростов-на-Дону) и в меньшей - от эпидемического процесса на смежных с областью территориях. Очевидно, что данные показатели были достигнуты благодаря своевременному и эффективному введению ограничительных мероприятий по перемещению граждан между субъектами Российской 
Федерации, а также мерами ограничения, действующими на территории Ростовской области.

Одной из задач при изучении эпидемиологических аспектов новой коронавирусной инфекции в Ростовской области является создание математической модели, позволяющей осуществлять прогнозирование развития эпидемического процесса распространения инфекции в области. На данный момент существуют различные классы математических моделей, применяемых для прогнозирования течения эпидемий: SRID, SIR, SIS, SEIR. Предназначены они для выбора вариантов возможных мер по снижению нагрузки на медицинские учреждения и определения сроков снятия ограничительных мер на основе прогнозных расчетов.

Была выбрана интерактивная модель SEIR (Susceptible - восприимчивый, Exposed - находящийся в инкубационном периоде, Infectious - инфицированный, Recovered - выздоровевший). Модель SEIR - самый распространенный инструмент для прогнозирования эпидемий и действенности мер по их подавлению. В 2020 г. модель была доработана Ричардом Нейером и его сотрудниками в Базельском университете с учетом особенностей эпидемии нового коронавируса ${ }^{1}$. Основное свойство этой модели - наличие так называемого эпидемического перехода: модель ведет себя радикально по-разному в зависимости от показателя $\mathrm{R}_{0}$ (коэффициент воспроизводства) - среднего числа людей, которых один инфицированный человек может заразить в течение периода своей болезни, то есть до полного выздоровления. При $\mathrm{R}_{0}$ меньше единицы эпидемия затухает, а при $\mathrm{R}_{0}$ больше единицы заражается значительная часть населения. Значение $\mathrm{R}_{0}$ зависит от особенностей вируса, доли населения, которое становится невосприимчивым к нему (в результате вакцинации или перенесенного заболевания), а также мер по подавлению эпидемии (например, социальное дистанцирование и карантин) [5]. Моделирование показывает, с какой скоростью будет распространяться эпидемия, сколько будет инфицированных, больных в критическом состоянии, а также летальных исходов.
На базе модели SEIR проведена обработка данных и анализ материалов по случаям заражения, тяжести течения заболевания у больных, случаев смерти от COVID-19 в Ростовской области с целью прогнозирования развития эпидемиологической ситуации ${ }^{2}$ [5]. Для построения адекватной модели эпидемии, вызванной новым коронавирусом, были определены критически важные параметры:

Численность популяции - 4197821 чел. (население Ростовской области на 01.01.2020 г.)

Возрастная структура популяции (табл.1)

- Начальное число зараженных COVID-19 - 200 (на начало моделирования).

- Количество коек для пациентов с COVID-19 2664, в отделениях интенсивной терапии - 969.

- Дата начала моделирования (25.03.2020) - дата первого выявленного случая COVID-19 в Ростовской области.

- Дата окончания моделирования - 01.09.2020.

- Среднегодовой коэффициент воспроизводства в отсутствие сдерживающих мер $\mathrm{R}_{0}=2,2$.

- Длительность латентного (незаразного) периода 3 дня.

- Продолжительность периода контагиозности 3 дня.

- Сезонность вируса - отсутствует.

- Эффективность мер противодействия - (режим самоизоляции, увеличение количества тестов и др.) $-70-75 \%$.

В соответствии с полученными результатами математического моделирования можно сделать вывод о том, что в Ростовской области на 01.09.2020 ожидается более 3000 активных заражений, около 400 госпитализированных, в том числе 24 человека в отделения интенсивной терапии; около 300 случаев смерти от COVID-19, а также более 194000 выздоровевших, включая лиц, не проходивших обследование на новую коронавирусную инфекцию и перенесших заболевание бессимптомно, либо в легкой форме (табл. 2), (рис. 6).

В соответствии с представленной моделью, эффективность мер противодействия (режим самозоляции,

\section{Возрастная структура популяции Ростовской области}

Таблица / Table 1. Age structure of the population of the Rostov region

\begin{tabular}{|c|c|c|}
\hline $\begin{array}{c}\text { Возрастная группа } \\
\text { Age }\end{array}$ & $\begin{array}{c}\text { Численность, чел. } \\
\text { Population }\end{array}$ & $\%$ \\
\hline $0-9$ & 535681 & $12,76 \%$ \\
\hline $10-19$ & 438842 & $10,45 \%$ \\
\hline $20-29$ & 448960 & $10,70 \%$ \\
\hline $30-39$ & 703841 & $16,77 \%$ \\
\hline $40-49$ & 586098 & $13,96 \%$ \\
\hline $50-59$ & 543593 & $12,95 \%$ \\
\hline $60-69$ & 532194 & $12,68 \%$ \\
\hline $70-79$ & 245934 & $5,86 \%$ \\
\hline $80+$ & 162678 & $3,88 \%$ \\
\hline Всего & 4197821 & $100 \%$ \\
\hline
\end{tabular}

\footnotetext{
${ }^{1}$ Моделирование эпидемий: дополнения к модели SIR: https://polit.ru/article/2020/05/27/sir.

${ }^{2}$ COVID-19 Scenarios. https://covid19-scenarios.org/.
} 
Таблица / Table 2.

\begin{abstract}
Прогноз эпидемиологической ситуации по COVID-19 в Ростовской области на 01.09.2020
в случае сохранения действующих ограничительных мер (данные моделирования)
\end{abstract}

Forecast of the epidemiological situation for COVID-19 in the Rostov region on 01.09.2020 in case of maintaining the current restrictive measures (modeling data)

\begin{tabular}{|l|c|}
\hline Число активных зараженных, чел. & 3152 \\
Number of active infected, people & 194253 \\
\hline Общее число выздоровевших, чел. & 403 \\
The total number of recovered people, people & 24 \\
\hline $\begin{array}{l}\text { Число госпитализированных, чел. } \\
\text { Hospitalized, people }\end{array}$ \\
\hline $\begin{array}{l}\text { Число госпитализированных в отделения интенсивной терапии, чел. } \\
\text { The пuтber of hospitalized in intensive care units, people }\end{array}$ \\
\hline $\begin{array}{l}\text { Общее число смертей, чел. } \\
\text { Total пuтber of deaths, people }\end{array}$ \\
\hline
\end{tabular}
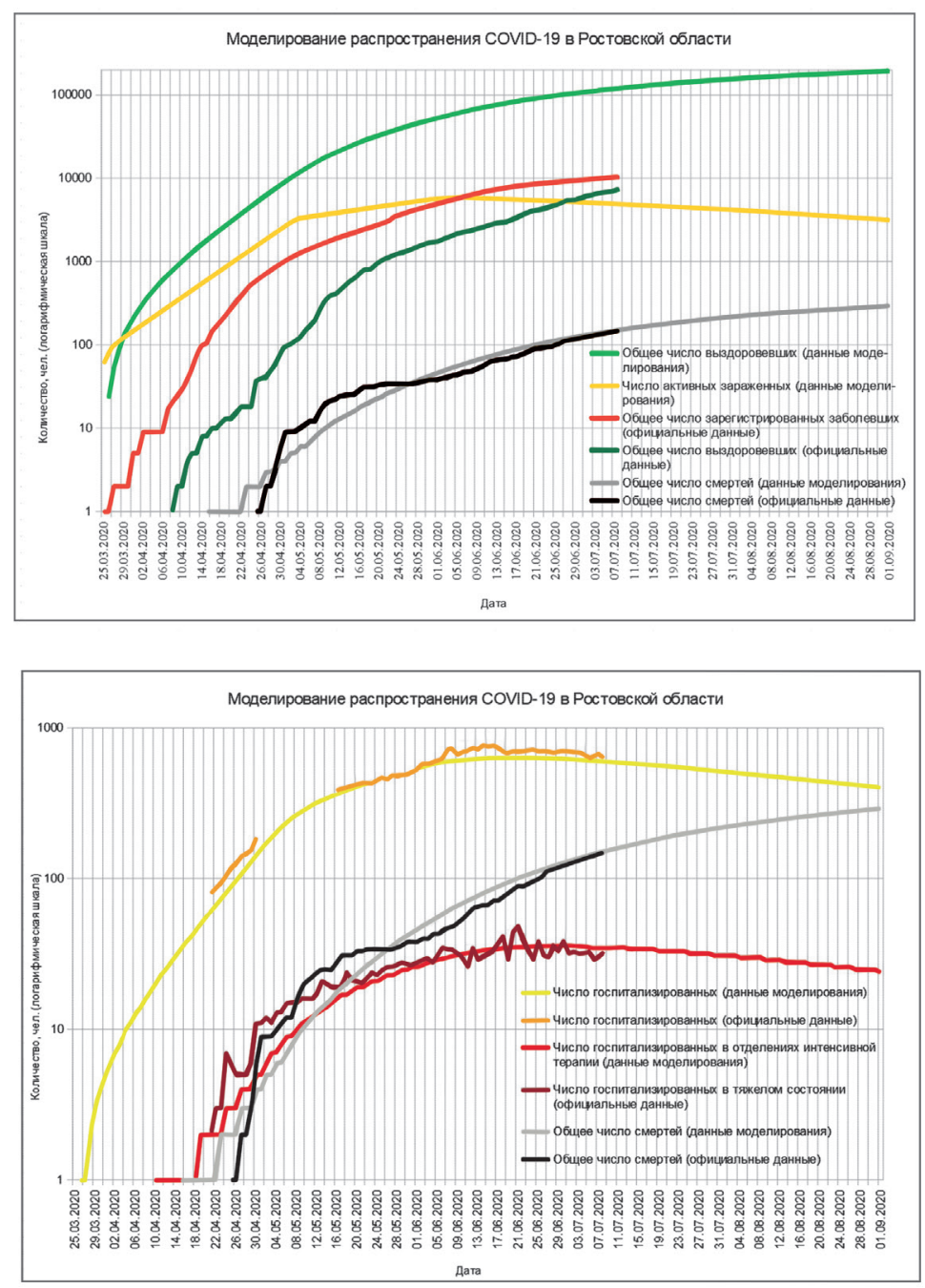

Рисунок 6. Прогноз эпидемиологической ситуации по COVID-19 в Ростовской области на 01.09.2020 в случае сохранения действующих ограничительных мер (данные моделирования).

Figure 6. Forecast of the epidemiological situation for COVID-19 in the Rostov region on 01.09.2020 in case of maintaining the current restrictive measures (modeling data).

масочный режим, социальное дистанцирование, увеличение количества тестов и др.) оценена на 76 \%. Сни- жение коэффициента $\mathrm{R}_{0}$ позволило на муниципальном уровне перейти к мероприятиям по ослаблению ограни- 
чительных мер. Однако важна постоянная актуализация эпидемиологических данных, так как при изменении используемых в моделировании параметров (коэффициент $\mathrm{R}_{0}$ и др.) прогноз на 01.09.2020 может измениться. На 10 июля 2020 г. результаты анализа свидетельствуют о том, что при сохранении сегодняшнего темпа и характера течения эпидемии COVID-19 в Ростовской области, можно предположить выявление антител к вирусу SARS-CoV-2 к концу рассматриваемого периода ориентировочно у $10 \%$ населения области. Для улучшения прогнозируемой ситуации необходимо продолжать осуществление комплекса мероприятий, направленных на реализацию в области ограничительных мер (масочного режима, социального дистанцирования граждан, проведения масштабных мероприятий по дезинфекции и пр.). Для определения более точного числа переболевших новой коронавирусной инфекцией необходимо существенно расширить масштабы проводимого в области серологического тестирования на антитела.

\section{Заключение}

В Российской Федерации с самого начала эпидемических проявлений COVID-19 в КНР взят курс на реализацию стратегии «опережающего реагирования», в соответствии с которой проводились и проводятся все противоэпидемические мероприятия. В соответствии с поручением премьер-министра 29 января 2020 г. создан Оперативный штаб по предупреждению завоза и распространения новой коронавирусной инфекции на территории Российской Федерации. С целью недопущения завоза COVID-19 в Российскую Федерацию мероприятия по мониторингу эпидемиологической ситуации начаты уже 31 декабря 2019 г. и по мере ухудшения эпидемиологической обстановки в странах мира дифференцированно вводились ограничения на въезд, вплоть до прекращения выдачи виз для всех иностранных граждан (Распоряжение Правительства Российской Федерации от 16 марта 2020 г. № 635-р). Данные меры позволили снизить темпы роста числа больных, прибывших из-за рубежа. Мероприятия, направленные на борьбу с передачей инфекции от человека к человеку внутри страны и соответственно на уровне регионов, также реализовывались по опережающему типу реагирования и вводились поэтапно с учетом развития эпидемического процесса в регионах.

В частности, в соответствии с Постановлением Главного государственного санитарного врача Российской Федерации от 02.03.2020 № 5 «О дополнительных мерах по снижению рисков завоза и распространения новой коронавирусной инфекции (2019-nCOV)», губернатором Ростовской области выпущено Распоряжение № 43 от 16.03.2020 «О введении режима повышенной готовности на территории Ростовской области и мерах по предотвращению распространения новой коронавирусной инфекции (2019-nCoV)».

На основании Постановления Главного государственного санитарного врача Российской Федерации от 18.03.2020 №7 «Об обеспечении режима изоляции в целях предотвращения COVID-19» на территории Ростовской области был введен режим самоизоляции. Управлением Роспотребнадзора по Ростовской области в соответствии с предоставляемыми отчетами на начало апреля прово- дился контроль исполнения Распоряжения Губернатора Ростовской области от 27.03.2020 №60 «О дополнительных мерах по предотвращению распространения новой коронавирусной инфекции (2019-nCoV)». Для предотвращения возникновения и ликвидации вспышек внутри лечебно-профилактических учреждений Главным государственным санитарным врачом по Ростовской области издано Постановление от 17.04.2020г № 4 "О дополнительных мерах по снижению рисков распространения новой коронавирусной инфекции (COVID-2019) и предупреждения внутрибольничного инфицирования". В связи с быстро меняющейся эпидемиологической ситуацией по новой коронавирусной инфекции на территории Ростовской области Главным государственным санитарным врачом по Ростовской области подготовлено Постановление № 5 «О внесении изменений в Постановление от 11 апреля 2020 г. № 3 «Об усилении ограничительных мероприятий».

С целью совершенствования лабораторной диагностики COVID-19 принято Постановление Главного государственного санитарного врача по Ростовской области от 05.05.2020 г. № 6 «Об упорядочении лабораторной диагностики COVID-2019 и других мероприятий». В соответствии с МР 3.1.0178-20 «Определение комплекса мероприятий, а также показателей, являющихся основанием для поэтапного снятия ограничительных мероприятий в условиях эпидемического распространения COVID-19» на конец июня 2020 г. коэффициент распространения инфекции в Ростовской области (Rt) составлял 0,92, а показатель охвата тестированием методом ПЦР на 100 тыс. населения 104,16 . Эти показатели пока не позволяли говорить о переходе на следующий этап снятия ограничений. Согласно данным по развитию эпидемиологической ситуации по COVID-19 на начало июля 2020 г. ситуация в Ростовской области оставалась стабильной. По данным Управления Роспотребнадзора по Ростовской области, на 10 июля 2020 г. ежедневное количество заражений новой коронавирусной инфекцией не превышало 100 случаев, а показатель заболеваемости на 100 тыс. населения в области был более чем в 1,5 раза ниже среднероссийского (251,0 против 447,0). С 13 июля по Распоряжению губернатора Донского региона вступает в силу очередной пакет мер по смягчению ограничений из-за коронавируса в Ростовской области (Постановление Правительства Ростовской области от 11.07.2020 № 631). Однако, как сообщил губернатор области, «пандемия никуда не ушла, это показывает статистика заболеваемости. По-прежнему, необходимым условием нормализации ситуации остается высокий уровень соблюдения санитарных правил. Находясь в общественных местах, на работе, необходимо строгое соблюдение санитарных норм».

Благодарность. Авторы выражают благодарность специалистам Управления Федеральной службы по надзору в сфере защиты прав потребителей и благополучия человека по Ростовской области и ФБУЗ «Центр гигиены и эпидемиологии в Ростовской области» за предоставленные сведения и статистическую обработку некоторых данных.

Acknowledgements. The authors are gratitude to the specialists of the Federal service for supervision of consumer protection and human welfare in the Rostov region and the Center for hygiene and epidemiology in the Rostov region for providing information and statistical processing. 
Финансирование. Исследование не имело спонсорской поддержки.

Finansing. The study did not have sponsorship.

\section{ЛИТЕРАТУРА}

1. Кутырев В.В., Попова А.Ю., Смоленский В.Ю., Ежлова Е.Б., Демина Ю.В., Сафронов В.А., Карнаухов И.Г., Иванова А.В., Щербакова С.А. Эпидемиологические особенности новой коронавирусной инфекции(COVID-19). Сообщение 1: Модели реализации профилактических и противоэпидемических мероприятий. // Проблемь особо опасных инфекицй. - 2020. - №1. - C.6-13. https://doi. org/10.21055/0370-1069-2020-1-6-13

2. Cao Y, Li L, Feng Z, Wan S, Huang P, Sun X, et al. Comparative genetic analysis of the novel coronavirus $(2019-\mathrm{nCoV} /$ SARS-CoV-2) receptor ACE2 in different populations. // Cell Discov. - 2020. - V.6. - P.11. https://doi.org/10.1038/s41421020-0147-1.

3. Donoghue M, Hsieh F, Baronas E, Godbout K, Gosselin M, Stagliano $\mathrm{N}, \mathrm{t}$ al. A novel angiotensin-converting enzyme-related carboxypeptidase (ACE2) converts angiotensin I to angiotensin 1-9. // Circ Res. - 2000. - V.87(5). - P.E1-9. https:// doi.org/10.1161/01.res.87.5.e1

4. Ларина В.Н., Головко М.Г., Ларин В.Г. Влияние коронавирусной инфекции (COVID-19) на сердечно-сосудистую систему // Вестник РГМУ. - 2020. - №2. - C. 5-13. https:// doi.org/10.24075/vrgmu.2020.020

5. Noll NB, Aksamentov I, Druelle V, Badenhorst A, Ronzani B, Jefferies G, et al. COVID-19 Scenarios: an interactive tool to explore the spread and associated morbidity and mortality of SARS-CoV-2. https://doi.org/10.1101/2020.05.05.20091363

\section{Информация об авторах}

Ковалев Евгений Владимирович, руководитель Управления Федеральной службы по надзору в сфере защиты прав потребителей и благополучия человека по Ростовской области, Ростов-на-Дону, Россия. E-mail: master@61. rospotrebnadzor.ru.

Твердохлебова Татьяна Ивановна, д.м.н., директор, Ростовский научно-исследовательский институт микробиологии и паразитологии Роспотребнадзора, Ростовна-Дону, Россия. ORCID: 0000-0002-3912-0291. E-mail: niimicrodouble@yandex.ru.

Карпущенко Гарри Викторович, к.м.н., главный врач, Центр гигиены и эпидемиологии в Ростовской области, Ростов-на-Дону, Россия. ORCID: 0000-0003-46728753. E-mail: master@donses.ru.

Ерганова Екатерина Геннадьевна, заместитель начальника Управления Федеральной службы по надзору в сфере защиты прав потребителей и благополучия человека по Ростовской области, г. Ростов-на-Дону, Российская Федерация. E-mail: master@61.rospotrebnadzor.ru.

Агафонова Виктория Владиславовна, к.б.н., заведующий отделом научно-технической деятельности, Ростовский научно-исследовательский институт микробиологии и паразитологии Роспотребнадзора, Ростовна-Дону, Россия. ORCID: 0000-0001-5331-4255. E-mail: niimicrodouble@yandex.ru.

Рындич Антонина Алексеевна, к.м.н., заведующий отделом эпидемиологии, Ростовский научно-исследовательский институт микробиологии и паразитологии Роспотребнадзора, Ростов-на-Дону, Россия. ORCID: 00000002-9568-7794. E-mail: niimicrodouble@yandex.ru.
Конфликт интересов. Авторы заявляют об отсутствии конфликта интересов.

Conflict of interest. Authors declares no conflict of interest.

\section{REFERENCES}

1. Kutyrev V.V., Popova A.Yu., Smolensky V.Yu., Ezhlova E.B., Demina Yu..V., Safronov V.A., et al Epidemiological Features of New Coronavirus Infection (COVID-19). Communication 1: Modes of Implementation of Preventive and Anti-Epidemic Measures. Problems of Particularly Dangerous Infections. 2020;(1):6-13. (In Russ.) https://doi.org/10.21055/03701069-2020-1-6-13

2. Cao Y, Li L, Feng Z, Wan S, Huang P, Sun X, et al. Comparative genetic analysis of the novel coronavirus (2019-nCoV/SARSCoV-2) receptor ACE2 in different populations. Cell Discov. 2020;6:11. https://doi.org/10.1038/s41421-020-0147-1.

3. Donoghue M, Hsieh F, Baronas E, Godbout K, Gosselin M, Stagliano N, t al. A novel angiotensin-converting enzymerelated carboxypeptidase (ACE2) converts angiotensin I to angiotensin 1-9. Circ Res. 2000;87(5):E1-9. https://doi. org/10.1161/01.res.87.5.e1

4. Larina V. N., Golovko M. G., Larin V. G. Effect of coronavirus infection (covid-19) on the cardiovascular system. Vestnik RGMU. 2020;(2):5-13. (in Russ.) https://doi.org/10.24075/ vrgmu. 2020.020

5. Noll NB, Aksamentov I, Druelle V, Badenhorst A, Ronzani B, Jefferies G, et al. COVID-19 Scenarios: an interactive tool to explore the spread and associated morbidity and mortality of SARS-CoV-2. https://doi.org/10.1101/2020.05.05.20091363

\section{Information about the authors}

Yevgeny V. Kovalev, head physician of Department of the Federal service for supervision of consumer protection and human welfare in the Rostov region, Rostov-on-Don, Russia. E-mail: master@61.rospotrebnadzor.ru.

Tatyana I. Tverdokhlebova, Dr. Sci. (Med.), Director of the Rostov research Institute of Microbiology and Parasitology, Rostov-on-Don, Russia. ORCID: 0000-0002-3912-0291. E-mail: niimicrodouble@yandex.ru.

Harry V. Karpushchenko, Cand. Sci. (Med.), head physician Center of hygiene and epidemiology in the Rostov region, Rostov-on-Don, Russia. ORCID: 0000-0003-46728753. E-mail: master@donses.ru.

Ekaterina G. Erganova, deputy head physician of Department of the Federal service for supervision of consumer protection and human welfare in the Rostov region, Rostov-onDon, Russian Federation. E-mail: master@61.rospotrebnadzor. ru.

Viktoriya V. Agafonova, Cand. Sci. (Biol.), head of the department of scientific and technical activities of the Rostov research Institute of Microbiology and Parasitology, Rostovon-Don, Russia. ORCID: 0000-0001-5331-4255. E-mail: niimicrodouble@yandex.ru.

Antonina A. Ryndich, Cand. Sci. (Med.), head of the department of epidemiology surveillance of HIV infection, Rostov research Institute of Microbiology and Parasitology, Rostov-on-Don, Russia. ORCID: 0000-0002-9568-7794. E-mail: niimicrodouble@yandex.ru.

Alexander G. Suladze, Cand. Sci. (Med.), head physician the centre for the fight against AIDS, Rostov research Institute 
Суладзе Александр Георгиевич, к.м.н., начальник Южного окружного центра по профилактике и борьбе со СПИДом, Ростовский научно-исследовательский институт микробиологии и паразитологии Роспотребнадзора, Ростов-на-Дону, Россия. ORCID: 0000-0002-9051-1220. E-mail: niimicrodouble@yandex.ru.

Колпаков Дмитрий Сергеевич, заведующий клинико-диагностической лабораторией, Ростовский научноисследовательский институт микробиологии и паразитологии Роспотребнадзора, Ростов-на-Дону, Россия. E-mail: niimicrodouble@yandex.ru.

Долгова Нина Николаевна, врач-эпидемиолог отдела эпиднадзора за ВИЧ-инфекцией Южного окружного центра по профилактике и борьбе со СПИДом, Ростовский научно-исследовательский институт микробиологии и паразитологии Роспотребнадзора, Ростовна-Дону, Россия. ORCID: 0000-0002-3218-3732. E-mail: niimicrodouble@yandex.ru.

Алексанина Наталья Владимировна, к.б.н., старший научный сотрудник лаборатории санитарной микробиологии водных объектов и микробной экологии человека, Ростовский научно-исследовательский институт микробиологии и паразитологии Роспотребнадзора, Ростовна-Дону, Россия. ORCID: 0000-0001-7702-1385. E-mail: niimicrodouble@yandex.ru.

Алешукина Анна Валентиновна, д.м.н., заведующий лабораторией вирусологии, микробиологии и молекулярно-биологических методов исследования, Ростовский научно-исследовательский институт микробиологии и паразитологии Роспотребнадзора, Ростов-на-Дону, Россия. ORCID: 0000-0002-9797-2441. E-mail: niimicrodouble@ yandex.ru.

Литовко Анна Радиковна, заведующий лабораторией вирусологических исследований, Центр гигиены и эпидемиологии, Ростов-на-Дону, Россия. E-mail: master@ donses.ru.

Алешукин Геннадий Сергеевич, инженер лаборатории вирусологии, микробиологии и молекулярно-биологических методов исследования, Ростовский научно-исследовательский институт микробиологии и паразитологии Роспотребнадзора, Ростов-на-Дону, Россия. E-mail: niimicrodouble@yandex.ru.

Денисенко Виктор Владимирович, инженер лаборатории вирусологии, микробиологии и молекулярно-биологических методов исследования, Ростовский научно-исследовательский институт микробиологии и паразитологии Роспотребнадзора, Ростов-на-Дону, Россия. E-mail: niimicrodouble@yandex.ru.

\section{Вклад авторов}

Т.И. Твердохлебова, В.В. Агафонова, А.А. Рындич, А.В. Алешукина, Н.В. Алексанина- разработка дизайна исследования;

Е.В. Ковалев, Г.В. Карпущенко, Е.Г. Ерганова, А.Р. Литовко, А.Г. Суладзе, Н.Н. Долгова, Д.С. Колпаков, Г.С. Алешукин, В.В. Денисенко - получение и анализ данных;

Т.И. Твердохлебова В.В. Агафонова, А.А. Рындич, Н.Н. Долгова - написание текста рукописи;

В.В. Агафонова, А.А. Рындич, Г.С. Алешукин, В.В. Денисенко - обзор публикаций по теме статьи. of Microbiology and Parasitology, Rostov-on-Don, Russia. ORCID: 0000-0002-9051-1220. E-mail: niimicrodouble@ yandex.ru.

Dmitry S. Kolpakov, head of the clinical and diagnostic laboratory of the Rostov research Institute of Microbiology and Parasitology, Rostov-on-Don, Russia. E-mail: niimicrodouble@ yandex.ru.

Nina N. Dolgova, epidemiologist department of epidemiology surveillance of HIV infection, Rostov research Institute of Microbiology and Parasitology. Rostovon-Don, Russia ORCID: 0000-0002-3218-3732. E-mail: niimicrodouble@yandex.ru.

Natalya V.Aleksanina, Cand. Sci. (Biol.), senior researcher at the laboratory of sanitary Microbiology of water bodies and human microbial ecology Rostov research Institute of Microbiology and Parasitology, Rostov-on-Don, Russia. ORCID: 0000-0001-7702-1385. E-mail: niimicrodouble@ yandex.ru.

Anna V. Aleshukina, Dr. Sci. (Med.), head of the laboratory of Virology, Microbiology and molecular biological research methods of the Rostov research Institute of Microbiology and Parasitology, Rostov-on-Don, Russia. ORCID: 00000002-9797-2441. ORCID: 0000-0002-9797-2441. E-mail: niimicrodouble@yandex.ru.

Anna R. Litovko, head of the laboratory of virological research at the Center for hygiene and epidemiology, Rostovon-Don, Russia. E-mail: master@donses.ru.

Gennady V.Aleshukin, engineer, laboratory of Virology, Microbiology and molecular biological research methods, Rostov research Institute of Microbiology and Parasitology, Rostov-on-Don, Russia. E-mail: niimicrodouble@yandex.ru.

Viktor V. Denisenko, engineer, laboratory of Virology, Microbiology and molecular biological research methods, Rostov research Institute of Microbiology and Parasitology, Rostov-on-Don, Russia. E-mail: niimicrodouble@yandex.ru.

\section{Authors contribution}

T.I. Tverdokhlebova, V.V. Agafonova, A.A. Ryndich, A.V. Aleshukina, N. V. Aleksanina - research design development;

E.V. Kovalev, G. V. Karpushenko, E.G. Erganova, A.R. Litovko, A.G., Suladze, N. N. Dolgova, D.S. Kolpakov, G.S. Aleshukin, V.V. Denisenko - obtaining and analysis of the data;

T.I. Tverdokhlebova V.V. Agafonova, A. A. Ryndich, N.N. Dolgova - writing the text of the manuscript;

V.V. Agafonova, A. A. Ryndich, G.S. Aleshukin, V.V. Denisenko - review of publications on the topic of the article. 